Niepełnosprawność. Dyskursy pedagogiki specjalnej

\title{
Agnieszka Lewicka-Zelent
}

Uniwersytet Marii Curie-Skłodowskiej w Lublinie

\section{Profilaktyczny i resocjalizacyjny wymiar mediacji w sprawach nieletnich}

Definiowanie pojęć „profilaktyka” i „resocjalizacja” nie nastręcza raczej problemów. Niemniej jednak można je tłumaczyć w różnych perspektywach, co bezpośrednio przekłada się na wybór odpowiednich metod oddziaływania na podopiecznych. Wśród nich nieletni stanowią szczególną grupę wychowanków pedagogów resocjalizacyjnych, z uwagi na większe możliwość wywierania na nich wpływu wychowawczego, aniżeli w przypadku dorosłych przestępców. Mediacja może być rozumiana jako jeden ze sposobów ich resocjalizacji oraz zapobiegania występowaniu u nich pewnych dysfunkcji w zakresie psychospołecznego funkcjonowania. Dokonano zatem próby wyodrębnienia zalet mediacji w sprawach nieletnich, podkreślając tym samym jej wagę w procesie ponownej socjalizacji młodzieży naruszającej normy prawne.

Słowa kluczowe: profilaktyka, resocjalizacja, mediacja, nieletni

\section{The preventive and rehabilitative dimensions of mediation in cases involving minors}

Defining concepts such as prevention and rehabilitation rarely poses any problems. Nevertheless, they can be explained from different perspectives, which directly translates into the selection of appropriate methods of exerting influence on the subjects. Among these, minors are a special group of rehabilitation pupils, given the greater opportunity to exert educational influence on them than on adult offenders. Mediation can be understood as a way to facilitate their social reintegration and preventing certain dysfunctions in the field of psychosocial functioning. Therefore, attempts have been made to isolate the advantages of mediation in cases involving minors, thus emphasizing its importance in the process of rehabilitation of young people violating legal norms.

Keywords: prevention, rehabilitation, mediation, minors

\section{Wprowadzenie w zagadnienia dotyczące profilaktyki i resocjalizacji}

Dane statystyczne świadczą o znacznym zdemoralizowaniu polskiej młodzieży, skutkiem czego jest poszukiwanie coraz to nowszych i bardziej skutecznych metod pracy wychowawczej. Niemniej jednak według A. Bałandynowicza [2008, 
s. 60] poglądy na temat sposobu oddziaływania wychowawczego na młodzież znacznie różnią się między sobą. Najczęściej przeważają dwa skrajne stanowiska. Przedstawiciele pierwszego z nich radykalnie opowiadają się za obniżeniem wieku odpowiedzialności karnej, czemu sprzeciwiają się pedagodzy, psycholodzy i prawnicy upatrujący metod pracy z młodymi ludźmi w założeniach psychologii humanistycznej. Uogólniając jednak społeczeństwu polskiemu bliższy jest pierwszy pogląd, w którym młodzież sprowadza się do poziomu funkcjonowania dorosłego przestępcy.

Autor niniejszego artykułu stoi na stanowisku, że jedynie w odpowiednio zaaranżowanych warunkach, w których podkreśla się ważną rolę nieletniego, możliwe jest skuteczne ukierunkowanie jego rozwoju, którego efektem finalnym będzie stosowanie się przez niego do norm społeczno-moralnych i prawnych. Dlatego warto jednoznacznie opowiedzieć się za konkretnym sposobem definiowania profilaktyki i resocjalizacji.

W świetle obowiązujących obecnie aktów normatywnych państwo zapewnia swoim niepełnoletnim obywatelom opiekę, która między innymi sprowadza się do podjęcia działań zapobiegawczych [Konwencja o prawach dziecka, 1989, art. 19]. Niełatwo jednak jednoznacznie określić, na czym polega ta profilaktyka, co wynika z wielości teorii stanowiących podbudowę tego pojęcia.

D. Rybczyńska [2008, s. 69] za K. Wojcieszkiem i J. Szymańską wskazuje na zalety tzw. profilaktyki problemowej, w obrębie której podejmuje się działania zmierzające do wykrycia czynników ryzyka oraz ochronnych - wspólnych dla różnych grup zachowań ryzykownych. Przykładowo R. Borum, P. Bartel i A. Forth [2002] wymieniają cztery grupy czynników ryzyka. Wyróżniają oni czynniki społeczne bezpośrednio dotyczące relacji interpersonalnych oraz indywidualne związane z jednostkowym funkcjonowaniem podmiotu w poszczególnych sferach rozwoju. Ponadto podkreślają istotną rolę czynników historycznych, w tym wcześniejszych doświadczeń jednostki, a także czynników ochronnych, których zadaniem jest minimalizowanie/niwelowanie negatywnych skutków wyżej wyróżnionych czynników ryzyka. W profilaktyce pozytywnej terminowi „czynniki chroniące" odpowiada termin „zasoby" [Ostaszewski 2003]. K. Mudyń [2003] twierdzi, że takie zasoby mogą tkwić zarówno w środowisko, jak i samej jednostce, a nabierają one sensu tylko i wyłącznie w relacji z potrzebami i celami podmiotu. Zasoby faktyczne podmiot uświadamia sobie i wykorzystuje podczas realizacji własnych potrzeb, natomiast potencjalne zasoby stanowią swoisty magazyn, $\mathrm{z}$ występowania którego jednostka zdaje sobie sprawę i być może w przyszłości skorzysta z jego zapasów. Zatem ważnym zadaniem wychowawczym jest nauczenie młodzieży formułowania własnych celów, dobranych do uświadomionych przez nią potrzeb, a następnie korzystania z zasobów faktycznych w życiu codziennym. K. Kumpfer [1999], A. Masten i J.L. Powell [2003] podkreślają różno- 
rodność zasobów, z których podmiot może czerpać. Niektóre z nich tkwią w nim samym (np. wysoki poziom kompetencji społecznych), a inne - w szeroko rozumianym środowisku społecznym lub środkach masowego przekazu [Rejman, Sak-Styczyńska 2008].

Takie podejście do profilaktyki można określić jako komplementarne, gdyż podkreślone zostają w nim dwa ważne aspekty wychowawczego oddziaływania na młodego człowieka. Według Z.B. Gasia [2000] taki sposób myślenia o profilaktyce sprzyja osiąganiu założonych celów wychowawczych. Przeciwstawiany jest natomiast "tradycyjnym" metodom definiowania tego pojęcia, w których eksponuje się konieczność przeprowadzenia diagnozy młodzieży, a następnie wyeliminowania występujących u niej: defektów, braków i niepożądanych zjawisk [np. Lipkowski 1971].

Z.B. Gaś [1999, s. 21] sprowadza profilaktykę do trzech poziomów. Profilaktyka pierwszorzędowa ma na celu „zapobieganie pojawianiu się problemów związanych z zachowaniami dysfunkcjonalnymi”, drugorzędowa - służy „ujawnieniu osób najbardziej zagrożonych wystąpieniem zaburzeń oraz pomaganiu im w redukcji tego ryzyka". Ostatni poziom profilaktyki dotyczy osób, u których wystąpiły już dysfunkcje wymagające podjęcia specjalistycznych oddziaływań. Profilaktyka trzeciorzędowa może być zatem utożsamiana z resocjalizacją, której zdefiniowanie nieustannie nastręcza wiele trudności. Obecnie klasyfikację tę coraz powszechniej zastępuje się innym podziałem, w którym wyróżnia się profilaktykę: uniwersalną, selektywną i wskazującą [Badora 2011], w których kryterium zakwalifikowania do danego rodzaju sprowadza się do stopnia zagrożenia młodzieży wystąpieniem zachowań ryzykownych [zob. Ostaszewski 2010].

Według M. Marczewskiego [2008, s. 77] określenie tego terminu jako „oddziaływanie wychowawcze na osoby niedostosowane do życia $w$ środowisku społecznym" jest zbyt ogólne. J. Szałański [2008, s. 16-17] wyróżnia dwa wymiary resocjalizacji, z których pierwszy ma charakter subiektywnej oceny zmian w zakresie swojego zachowania. Natomiast drugi jest obiektywny z punktu widzenia obserwowalnych zmian $\mathrm{w}$ sposobie przestrzegania norm społecznych i prawnych. Zatem o osobie zresocjalizowanej można mówić, gdy zostaną „zaobserwowane pozytywne, sprzyjające integracji społecznej, zmiany zachowania w następstwie korektury wadliwych mechanizmów psychologicznych regulacji zachowania bądź w następstwie "zainstalowania" (uformowania od podstaw) mechanizmów niezbędnych do bezkolizyjnego zachowania".

Problem praktyczny sprowadza się do określenia poziomu skuteczności resocjalizacyjnej. Jak twierdzi Z. Bartkowicz [2008] pojęciem kluczowym w tym względzie staje się ,"korzystna zmiana” , która dotyczy zachowania podmiotu oraz jego osobowości. Nie chodzi jednak o to, aby ktoś próbował grać, zachowując się zgodnie z oczekiwaniami innymi ludzi, a o to, aby postępował zgodnie z własnymi 
przekonaniami i normami danej grupy społecznej. Jednak, jak pisze J. Szałański [2008; por. Machel 2003, s. 21] zdecydowanie trudniej jest osiągnąć trwałe przemiany wewnętrzne, czyli tzw. cel maksimum. Być może z uwagi na brak rzetelnych analiz dotyczących skuteczności resocjalizacji [Bartkowicz 2008; Sakowicz 2008] większa część społeczeństwa twierdzi, że podejmowane oddziaływania nie przynoszą oczekiwanych rezultatów. T. Sakowicz [2008] poddaje w wątpliwość, m.in. dzięki rozważaniom D. Kowalskiej i I. Ryciak, skuteczność zakładowej resocjalizacji nieletnich, co przemawia za otwartymi formami resocjalizacji młodzieży.

Młodzi ludzie objęci są obowiązkiem szkolnym, co zmusza nauczycieli do podjęcia działań pomocowych na ich rzecz. Według J. Rejmana i A. Sak-Styczyńskiej [2008] współczesna szkoła nie wywiązuje się jednak ze swojej profilaktycznej funkcji. Co więcej, niektóre z podejmowanych na jej terenie działań sprzyjają marginalizacji i etykietyzacji uczniów. Autorzy zarzucają szkołom przewagę dydaktyzmu nad wychowaniem, stosowanie w przeważającej większości metod kontrolno-oceniających, niedocenianie współpracy z interesariuszami zewnętrznymi i ignorowanie problemów wychowawczych uczniów. Dodatkowo T. Lewandowska-Kidoń [2008] nieskuteczności profilaktyki w szkołach uparuje w podejmowaniu raczej okazjonalnych działań profilaktycznych, a nie systemowych i ciągłych. Znaczą przeszkodą w realizacji zadań profilaktycznych szkół jest również niski poziom kompetencji nauczycieli w zakresie rozwiązywania problemów wychowawczych młodzieży. Wyniki badań M. Przybysz-Zaremby [2008] dowodzą, że pracownicy szkół najczęściej sięgają po najprostsze, nie zawsze skuteczne, sposoby zapobiegania demoralizacji młodzieży.

\section{Postępowanie z nieletnimi}

Obowiązująca aktualnie Ustawa o postępowaniu w sprawach nieletnich reguluje sposób obchodzenia się z osobami nieletnimi, które dopuściły się czynów karalnych. Pomimo, że akty normatywne zakładają eliminację kar wobec najmłodszych obywateli Polski, to środki stosowane wobec nich najczęściej właśnie w taki sposób oceniane są przez nich samych. Ogólnie w historii prawa przeważają dwa skrajnie zróżnicowane podejścia do kary. E.A. Wdzięczna [2010] za: A. Gaberle [2006] zwraca uwagę, że w jednym z podejść najważniejsze jest ukaranie sprawcy, a w drugim - ochrona obywateli. Autorka [2010, s. 24] twierdzi, że „w tych obu koncepcjach, pomimo wszelkich różnic w podejściu do czynu przestępnego i jego sprawcy, wymiar sprawiedliwości pojmowany jest przede wszystkim jako relacja między sprawcą a państwem, zaś pokrzywdzony i restytucja zajmują miejsce i znaczenie co najwyżej symboliczne". W historii prawa (nie 
tylko polskiego) dominowało odwetowe podejście do kary, co jak uważa E.A. Wdzięczna [2010], skłoniło badaczy do podejmowania badań nad skutecznością sprawiedliwości retrybutywnej. W świetle uzyskanych wyników badań uznano, że kara sprzyja wyeksponowaniu siły państwa nad obywatelami. Wobec tego rozpoczęto poszukiwania pewnych alternatyw w podejściu do osób naruszających normy prawne. Zgodnie z założeniem, że przestępstwo, sprawca i ofiara stanowią trzy nierozerwalne elementy [Hołyst 2011], środek ciężkości przesunięto ze sprawcy na osobę pokrzywdzoną. Stale wzrasta zainteresowanie założeniami sprawiedliwości naprawczej, w której dobro ofiar stanowi nadrzędną zasadę w reakcji na przestępstwo [E.A. Wdzięczna, 2010]. Polska znajduje się wśród państw, które w ostatnich latach coraz bardziej otwierają się na alternatywne sposoby rozwiązywania konfliktów prawnych. Możliwość udziału w mediacji mają nieletni dzięki odpowiednim zapisom w UPN z dnia 26 października 1982 r. ze zm. z 2000 r. [Załącznik do obwieszczenia Marszałka Sejmu Rzeczypospolitej Polskiej 20.02.2014 r., poz. 382]. Zgodnie z art. 3a § 1 sąd rodzinny w każdym momencie trwania postępowania sądowego, z własnej inicjatywy, strony lub stron konfliktu może skierować sprawę do mediacji. Tak, jak zapowiada ten sam artykuł § 3, szczegółowe zasady postępowania mediacyjnego wyznacza Rozporządzenie Ministra Sprawiedliwości z dnia 18 maja 2001 r. w sprawie postępowania mediacyjnego w sprawach nieletnich [RMS - Dz. U. z 2001 r. Nr 56, poz. 591].

\section{Walory mediacji w sprawach nieletnich}

Obecnie nieletni mają możliwość uczestniczenia w spotkaniach mediacyjnych, w których wraz z osobami pokrzywdzonymi poszukują satysfakcjonującego ich rozwiązania zaistniałego konfliktu.

W przeciwieństwie do postępowania sądowego, w mediacji nie chodzi o ukaranie sprawcy, zemstę na nim, czy „równe i sprawiedliwe” wywołanie u niego odczuć takich, jakich doświadczyła ofiara. W procesie retrybucji nie ma miejsca na poglądy uczestników konfliktu prawnego, natomiast $\mathrm{w}$ restytucji mają oni taką możliwość, co spełnia funkcję motywacyjną do podjęcia trudu włączenia się w proces zadośćuczynienia przez wszystkie zainteresowane strony [Lewicka-Zelent 2015].

Celem mediacji jest samodzielne wypracowanie przez nieletniego i osobę pokrzywdzoną rozwiązania konfliktu o charakterze prawnym. Osobiste zaangażowanie stron konfliktu zwiększa ich autonomię, a równocześnie prawdopodobieństwo dotrzymania zobowiązań podjętych podczas spotkań mediacyjnych. W trakcie mediacji nieważne jest dochodzenie prawdy, wskazywanie winnego i umyślne wywoływanie w nim poczucia wstydu oraz wyrzutów sumienia, które 
często skutkują wzrostem poziomu agresji podmiotu. Zarówno nieletni, jak i osoba, która poniosła stratę, mają możliwość wyrażenia doświadczanych emocji oraz wyartykułowania potrzeb, ważnych z punktu widzenia jakości relacji z partnerem interakcji. Podczas spotkań mediacyjnych nieletni wyjaśnia zaistniałą sytuację z własnej perspektywy, a dzięki temu czasami może spodziewać się pewnej dozy „życzliwości” ze strony osoby pokrzywdzonej, która ma okazję poznania przyczyn zachowania nieletniego i uwolnienia się od poczucia winy za dane zdarzenia, a także obniżenia poziomu lęku przed sprawcą i zdjęcia z siebie ciężaru „bycia ofiarą". Ponadto poczucie sprawczości i decyzyjności, jakich doświadczają strony konfliktu wzmacnia ich przekonanie o własnej wartości oraz możliwości decydowania i samostanowienia o sobie samym. Takie przekonania z kolei sprzyjają przejęciu odpowiedzialności za popełnione błędy i podjęciu przez nieletniego działań restytucyjnych na rzecz pokrzywdzonego. Błędne jest jednak założenie, że mediacja zmierza ku poprawie relacji społecznych, aczkolwiek prawdą jest, że przyczynia się do zatrzymania eskalacji konfliktu lub przynajmniej nie zaostrzania go oraz ogranicza jego zasięg w kontekście kolejnych sprzymierzeńców stron konfliktu [Lewicka, Grudziewska, 2010; Lewicka-Zelent 2015; zob. Rękas 2010, s. 46, 50].

W procesie resocjalizacji ważne znaczenie odgrywa wsparcie udzielane osobom, które po raz wtóry pragną nauczyć się właściwego - zgodnego z normami społeczno-moralnymi - funkcjonowania w społeczeństwie. Nieletni uczestnicząc w spotkaniach mediacyjnych nie pozostają sami, w poczuciu osamotnienia. Tuż obok są ich najbliżsi - rodzice lub opiekuni prawni, którzy nie przejmują jednak za nich odpowiedzialności za ich naganne zachowanie [§10 RMS]. W życiu codziennym rodzice często nieświadomie popełniają szereg błędów wychowawczych, pełnych nadmiernej opiekuńczości, czy zbyt wysokich wymagań, w konsekwencji których młodzi ludzie usprawiedliwią swoje postępowanie. Podczas mediacji rodzice nie mogą jednak pozwolić sobie na takie zachowanie względem swoich dzieci, gdyż swoje poglądy, opinie, emocje, czy propozycje rozwiązań wyrażają i zgłaszają jedynie nieletni. Z całą pewnością służy to zrozumieniu przez nich tego, że to oni ponoszą konsekwencje naruszania norm prawnych. Właśnie $\mathrm{z}$ tego powodu mediacja stanowi lekcję odpowiedzialności dla młodych ludzi [zob. Rękas 2010, s. 47]. Uwieńczeniem postępowania mediacyjnego jest spisanie ugody mediacyjnej [\$17, pkt. 4 RMS], w której zawiera się wszelkie zobowiązania stron konfliktu, a która zatwierdzona przez sąd nabiera mocy prawnej, co w znacznym stopniu może motywować nieletniego do właściwego zachowania - zgodnie z obowiązującymi normami społecznymi i prawnymi. Prawdopodobieństwo zadośćuczynienia osobie pokrzywdzonej wzrasta wraz ze wzrostem jego wewnętrznej motywacji do naprawienia popełnionych błędów i samodzielności wypracowania rozwiązania konfliktu. Trudniej jest bowiem złamać dane słowo 
(dodatkowo na piśmie) aniżeli nie respektować nakazów nałożonych przez inne osoby (np. arbitra, czy sąd). Z perspektywy psychopedagogicznej spisanie ugody przypomina przygotowanie kontraktu, który stanowi istotne narzędzie w pracy profilaktycznej i resocjalizacyjnej [Lewicka-Zelent 2015; zob. Rękas 2010, s. 51].

Podobnie, jak w przypadku mediacji w sprawach karnych, mediacja z udziałem nieletnich, umożliwia stronom odreagowanie negatywnych emocji, które odbierają im radość z życia. Ponadto postępowanie mediacyjne wiąże się z niższym poziomem stresu - bardzo często będącym przyczyną agresji - w porównaniu z postępowaniem mediacyjnym. Podczas mediacji nieletni zobligowani są do wysłuchania osoby pokrzywdzonej i podjęcia próby ustalenia, wspólnie z nią, formy zadośćuczynienia w czasie sześciu tygodni [\$9 RMS], co oznacza, że napięcie towarzyszące stronom mediacji trwa znacznie krócej niż rozprawa sądowa. Tym samym możliwy jej szybszy ich powrót do takiego sposobu funkcjonowania, jak przed pojawieniem się konfliktu prawnego. $W$ takiej sytuacji łatwiej jest im zachować kontrolę nad własnym życiem [zob. Rękas 2010, s. 47].

Wniosek o mediację może złożyć każda strona konfliktu i świadomie zgodzić się na uczestnictwo w niej [§11 RMS], co sprzyja zwiększeniu poczucia zrównania praw nieletniego z prawami osób pokrzywdzonych. Z psychologicznego punktu widzenia sprawca może poczuć się ważny i doceniony, dzięki czemu zechce podjąć dialog mający na celu znalezienie odpowiedniej formy zadośćuczynienia. Natomiast podjęcie działań naprawczych na rzecz ofiary dają nieletniemu szansę uniknięcia stygmatyzacji społecznej, z którą mają do czynienia wszyscy ci, wobec których sąd stosuje środki przewidziane w UPN [zob. Rękas 2010, s. 47, 49].

Spotkania mediacyjne można potraktować również jako lekcje zmierzające do podniesienia świadomości mediacyjnej stron oraz rozwijania ich kompetencji komunikacyjnych [Lewicka 2008]. Okazję ku temu stanowią kolejne spotkania, podczas których strony dowiadują się, czym jest mediacją, jakimi zasadami kieruje się ona, jakie im przysługują prawa mediacyjne i jakie korzyści mogą uzyskać oni z udziału w niej. Mediacja często stanowi proces inicjacyjny w zakresie komunikacyjnym. Zachowanie unikowe stron (bardzo często obrażanie się i towarzyszące jemu milczenie) przyczynia się do przerwania relacji między nimi, natomiast spotkanie mediacyjne stanowi doskonałą okazję do szczerej, konstruktywnej rozmowy, w której jest miejsce zarówno na asertywność, jak i empatię [Lewicka 2008; Zubrzycka-Maciąg 2008]. Mediator wpisany do wykazu (na listę mediatorów w sądzie okręgowym) jest profesjonalistą, który poza wiedzą z zakresu prawa, socjologii, psychologii i pedagogiki resocjalizacyjnej, posiada praktyczne umiejętności wspomagania stron podczas rozwiązywania konfliktów [Dz. U. z 2001 r. Nr 56, poz. 591]. Dba on o pozytywną atmosferę, w której jest przestrzeń na: otwartość, szczerość, empatię i zrozumienie oraz uczciwość. Rozwijanie kompetencji społecznych stanowi jedno z ważnych zadań zarówno profilaktycznych, 
jak i resocjalizacyjnych. $Z$ jednej strony zapobiega bowiem naruszaniu praw innych ludzi, a z drugiej zwraca uwagę nieletnim na potrzeby drugiego człowieka, co jest warunkiem koniecznym do rozpoczęcia procesu włączania się do społeczeństwa [Lewicka, Grudziewska 2010; Wojnarska 2010; Zubrzycka-Maciąg 2011].

Podczas mediacji obowiązują pewne zasady, których przestrzeganie wyznacza odpowiedni kierunek procesu konstruktywnego rozwiązywania konfliktów. Pierwsza z nich zakłada dobrowolne przystąpienie przez osoby zaangażowane w konflikt do postępowania mediacyjnego. Zasada dobrowolności, bezstronności i neutralności pośrednika [PCM, 2003], wyrażające się w podejściu podmiotowym i pełnym zaufania do człowieka, zwiększają motywację wewnętrzną stron do podjęcia próby włączenia się do procesu restytucyjnego. Dlatego można oczekiwać, że uzyskane efekty - wypracowane porozumienie - będą bardziej długotrwałe i efektywne w porównaniu do rozstrzygnięcia sądowego, na wynik którego nieletni nie ma większego wpływu. $\mathrm{Z}$ tego względu mediacja może służyć wdrażaniu młodego człowieka do przestrzegania norm społeczno-moralnych i prawnych, tak istotnych w procesie resocjalizacji [Lewicka-Zelent, 2015].

Zasada poufności [§12 RMS; PCM, 2003] gwarantuje stronom zachowanie w tajemnicy zachowań, których często wstydzą się. Podczas spotkań mediacyjnych jest bowiem przestrzeń na wyrażanie swoich negatywnych emocji, znajdujących odzwierciedlenie w postaci niecodziennych reakcji, np. płaczu. Strony są jednak świadome, że inni członkowie społeczeństwa nie zobaczą tego, czego nie powinni. W trakcie postępowania sądowego nie mają takiej gwarancji. Dodatkowo spotkania mediacyjne stanowią swoisty trening empatii, z deficytami której "walczą" pedagodzy - w tym ci realizujący zadania resocjalizacyjne. Strony uczę się nazywać swoje potrzeby i emocje oraz odczytywać i zaspokajać je u partnera interakcji [Lewicka-Zelent 2014b].

$\mathrm{W}$ procesie resocjalizacji i w każdym innym, w którym w grę wchodzi wspieranie innych ludzi (np. profilaktycznym) ważną rolę odgrywają wychowawcy, interwenci, terapeuci itp. Podobnie jest $w$ mediacji, w której podstawowym zadaniem pośrednika jest zapewnianie stronom odpowiedniego klimatu do dialogu. Zasada akceptowalności [PCM, 2003] gwarantuje stronom, że mediator będzie właściwie wybraną osobą, facylitującą proces poszukiwania przez nie konstruktywnego rozwiązania konfliktu. Zdecydowanie łatwiej jest szczerze wyrażać swoje emocje mając poczucie autentycznego wsparcia ze strony innej osoby i spróbować aktywnie i zgodnie z obowiązującymi normami oraz zasadami wejść po raz kolejny w społeczeństwo [Lewicka-Zelent 2015].

Badania empiryczne, których celem było sprawdzenie, w jakim zakresie uczestnictwo przez nieletnich $\mathrm{w}$ mediacji może spełniać funkcję resocjalizacyjną doprowadzily do pewnych wniosków. Osoby, które dopuściły się czynu zabronionego prawnie w $44 \%$ przeprosiły osoby pokrzywdzone i złożyły obietnice 
zaprzestania wobec nich działań szkodliwych, w 20\% zadośćuczyniły w sposób finansowy, a w 4\% wykonały pewne usługi na ich rzecz [Gołąb 2006]. Natomiast A. Lewicka i E. Grudziewska [2010] dowiodły, że 72\% nieletnich pod nadzorem kuratora i 83\% wychowanków młodzieżowego ośrodka wychowawczego chciałoby przekazać pieniądze pobitej ofierze. Zdecydowanie mniej młodzieży zdecydowałoby się na przeprosiny tej osoby. Z badań A. Lewickiej-Zelent [2015] wynika, że ogólnie łatwiej jest zadośćuczynić osobie pokrzywdzonej w formie materialno-finansowej lub usługowej aniżeli w formie emocjonalnej - wyrażenia skruchy, czy oficjalnego przyznania się do błędu.

\section{Implikacje praktyczne}

W kontekście prowadzonych rozważań nad profilaktyczną i resocjalizacyjną funkcją mediacji można sformułować wniosek o konieczności podnoszenia mediacyjnej świadomości społecznej w aspekcie walorów tego alternatywnego sposobu rozwiązywania konfliktów. Aktualnie obowiązujące polskie akty normatywne umożliwiają wykorzystywanie mediacji podczas poszukiwania rozwiązań konfliktów prawnych. Nieletni w większości spraw sądowych mają prawo do podejmowania działań naprawczych na rzecz osób pokrzywdzonych.

Zatem „nowym” zadaniem pedagogów i psychologów pracujących z młodzieżą jest stworzenie jej odpowiednich warunków do podjęcia dialogu ze skonfliktowanymi osobami. Dlatego niezbędne jest wyposażenie wychowawców w kompetencje mediacyjne - w tym w wiedzę o mediacji, umiejętności jej prowadzenia oraz cechy ułatwiające stronom dojście do porozumienia. W tym celu mogą oni skorzystać z dość bogatej oferty szkoleniowej, w postaci kursów, warsztatów i studiów podyplomowych. Ważne jest jednak zadbanie o wysoki poziom merytoryczny i metodyczny tych form kształcenia. ${ }^{1}$ Również w ofercie programowej wielu ośrodków akademickich znajdują się zajęcia poruszające tematykę mediacji, co może stanowić pierwszy krok ku zainteresowaniu przyszłych pedagogów i psychologów tymi zagadnieniami. Odpowiednio wykształcone osoby mogą z powodzeniem realizować programy mediacyjne lub/i prowadzić spotkania mediacyjne z udziałem nieletnich. Nie ma bowiem przeciwskazań ku temu, aby podjęto się takich zadań w zakładach poprawczych, ośrodkach socjoterapeutycznych i wychowawczych, czy ośrodkach kuratorskich [Lewicka-Zelent 2014a].

Z drugiej zaś strony mediację można wykorzystywać w celu zapobiegania nieprzystosowaniu społecznemu młodzieży, dzięki realizacji programów media-

1 Przykład taki stanowią Studia Podyplomowe w zakresie Mediacji Szkolnej i Sądowej prowadzone na Wydziale Pedagogiki i Psychologii UMCS w Lublinie. 
cyjnych w szkołach, internatach i bursach szkolnych. Rozwijanie kompetencji mediacyjnych przyszłych mediatorów-rówieśników pełni bowiem funkcję profilaktyczną, w kontekście uwrażliwiania młodzieży i wzmacniania pozycji wartości prospołecznych $w$ jej hierarchii [Lewicka-Zelent 2014b]. T. Pilch [1995] sugeruje, że działania podejmowane przez pracowników szkół powinny zmierzać w kierunku rozwijania u uczniów właśnie konstruktywnych sposobów rozwiązywania konfliktów, pozbawionych niezdrowej rywalizacji i przemocy. W Polsce prowadzone są $\mathrm{z}$ powodzeniem szkolne programy mediacyjne, które przynoszą zakładane efekty w postaci wzmocnionych zasobów osobistych młodzieży [np. Lewicka-Zelent 2014b]. Poza tym nieletni uczęszczający do szkól, w których prowadzone są mediacje mogą uczestniczyć w nich, ucząc się przejmowania odpowiedzialności za swoje postępowania oraz przyznawania się do popełnionych błędów, a potem podejmowania próby ich naprawy - chociażby (a może aż) poprzez umiejętność szczerego wypowiedzenia słowa "przepraszam”. Analizując założenia realizowanych szkolnych programów mediacyjnych, ich przebieg i wyniki przeprowadzonej ewaluacji można pokusić się o stwierdzenie, że mediacja może być wykorzystywana na każdym z trzech poziomów oddziaływań profilaktycznych. Znajduje ona zastosowanie w profilaktyce pierwszo-, drugo- i trzeciorzędowej, wobec osób, u których brakuje przejawów dysfunkcjonalności oraz u tych, wobec których podejmowane są już oddziaływania resocjalizacyjne - wobec nieletnich ${ }^{2}$.

Na gruncie przepisów prawnych dotyczących nieletnich proponowane są zmiany. Krajowa Rada Sądownictwa wydając opinię w przedmiocie projektu ustawy o zmianie ustawy o postępowaniu w sprawach nieletnich stwierdza, że wstrzymywanie się przez sąd rodzinny z zakończeniem procesu do chwili realizacji postanowień zawartych $\mathrm{w}$ ugodzie będzie skutkowało przewlekłością procesową. Trudno nie zgodzić się z tym, że w takiej sytuacji wydłuży się czas postępowania sądowego, aczkolwiek sąd w większym stopniu będzie miał kontrolę nad wykonalnością zawieranych ugód. Na podstawie faktów będzie mógł zaproponować dalszy kierunek resocjalizacji nieletniego. Sam sposób wykonania ugody może wiele powiedzieć - na ile nieletni świadomie podjął działania restytucyjne na rzecz pokrzywdzonego, a na ile kierował się przesłankami złagodzenia konsekwencji swojego nagannego zachowania. Wątpliwości budzi jednak stanowisko Krajowej Rady Sądownictwa w aspekcie stwierdzenia: „Należy się też zastanowić, na ile dziecko może być świadomym uczestnikiem mediacji z dorosłym pokrzywdzonym i zawierać z nim ugodę." Wyniki badań nad prowadzonymi dotychczas mediacjami z udziałem młodzieży potwierdzają, że nieletni są w stanie świadomie podjąć dialog z osobą pokrzywdzoną. Oczywiście w kontekście psy-

2 Klasyfikacja oddziaływań profilaktycznych przyjęta za Z.B. Gasiem [1998]. 
chologii rozwojowej zakładamy, że poziom rozwoju społeczno-moralnego ludzi w tym samym wieku jest zróżnicowany, z uwagi na różnorodne uwarunkowania natury biologicznej i społecznej. Przyjmując taki tok rozumowania można stwierdzić, że wielu ludzi dorosłych nie można uznać za świadomych uczestników mediacji sądowych. Dlatego może warto zastanowić się nad sposobem kwalifikowania spraw do mediacji - biorąc pod uwagę stopień psychospołecznego rozwoju sprawców ${ }^{3}$. Słuszne natomiast wydaje się zwrócenie uwagi Krajowej Rady Sądownictwa na fakt, że możliwość nadania klauzuli wykonalności na ugodę zawartą przez nieletniego będzie skutkowała przerzuceniem odpowiedzialności - $\mathrm{w}$ aspekcie finansowym - na rodziców i opiekunów prawnych. W ten sposób mediacja przestanie pełnić jedną z podstawowych swoich funkcji - przejmowania odpowiedzialności za swoje postępowanie.

Warto zatem przed zaakceptowaniem nowych rozwiązań prawnych dotyczących nieletnich przyjąć za Krajową Radą Sądownictwa, że „,mediacja w sprawach nieletnich powinna zostać uregulowana odmiennie, aniżeli w sprawach osób dorosłych. Należy położyć nacisk na jej charakter wychowawczy, a nie naprawczy"

\section{Bibliografia}

Badora S. (2011), Profilaktyka pedagogiczna [w:] Profilaktyka i resocjalizacja, Z. Bartkowicz, P. Maciaszczyk (red.), PWSZ, Tarnobrzeg, s. 11-30.

Bałandynowicz A. (2008), Profilaktyka i resocjalizacja jednostki w środowisku otwartym [w:] Dylematy wspótczesnej profilaktyki i resocjalizacji, A. Kieszkowska (red.), UHP, ŚCPiE, Kielce, s. 53-65.

Bartkowicz Z. (2008), Skuteczna resocjalizacja w perspektywie aksjologicznej i pomiarowej [w:] Skuteczna resocjalizacja. Doświadczenia i propozycje, Z. Bartkowicz, A. Węgliński (red.), UMCS, Lublin, s. 23-28.

Borum R., Bartel P., Forth A. (2002), Manual for the Structured Assessment of Violence Risk in Youth, Version 1, Florida.

Gaś Z.B. (1998), Wybrane zagadnienia psychoprofilaktyki, UMCS, Lublin.

Gaś Z.B. (1999), Młodzieżowe programy wsparcia rówieśniczego, BPS, Katowice.

Gaś Z. B. (2000), Psychoprofilaktyka. Procedury konstruowania programów wczesnej interwencji, UMCS, Lublin.

3 Dla przykładu A. Lewicka-Zelent [2015] proponuje ustalać poziom gotowości nieletnich do zadośćuczynienia, co zwiększa prawdopodobieństwo uzyskania efektywnego rozwiązania konfliktu na drodze mediacji, opartego na wewnętrznym przekonaniu podmiotu o konieczności naprawy swoich błędów.

4 Opinia Krajowej Rady Sądownictwa z dnia 10 lutego 2011 r. w przedmiocie projektu ustawy o zmianie ustawy o postępowaniu w sprawach nieletnich. 
Gołąb A. (2006), Miejsce mediacji w resocjalizacji nieletnich. Doniesienie z badań przeprowadzonych w Sądzie Rejonowym w Legnicy [w:] Wybrane problemy profilaktyki i resocjalizacji na tle porównawczym, Z. Jasiński, D. Widelak (red.), Wydawnictwo Wisza, Opole.

Hołyst B. (2011), Kryminologia, Lexis Nexis, Warszawa.

Kodeks Etyki Mediatora, PCM, Warszawa 2003.

Kumpfer K. (1999), Factors and processes contributing to resilience. The resilience framework [in:] Resilience and Development. Positive Life Adaptations, M.D. Glantz, J.L. Johnson (eds.), Kluwer Academic/Plenum Publishers, New York, s. 179-224.

Lewandowska-Kidoń T. (2008), Blaski i cienie profilaktyki w gimnazjum [w:] Skuteczna resocjalizacja. Doświadczenia i propozycje, Z. Bartkowicz, A. Węgliński (red.), UMCS, Lublin, s. 259-273.

Lewicka A. (red.) (2008), Profesjonalny mediator. Zostań nim. Poradnik metodyczny, UMCS, Lublin.

Lewicka A., Grudziewska E. (2010), Mediacja sądowa. Alternatywna metoda resocjalizacyjna?, UMCS, Lublin.

Lewicka-Zelent A. (2014a), Klimat szkót gimnazjalnych. Diagnoza weryfikacyjna programu. Mediacja w szkole, SCRIPTORIUM, Opole.

Lewicka-Zelent A. (2014b), Analiza zasobów osobistych uczestników szkolnego warsztatu mediacyjnego, SCRIPTORIUM, Opole.

Lewicka-Zelent A. (2015), Uwarunkowania gotowości nieletnich do zadośćuczynienia w paradygmacie sprawiedliwości naprawczej, UMCS, Lublin.

Lipkowski O. (1971), Dziecko społecznie niedostosowane i jego resocjalizacja, PZWS, Warszawa.

Machel H. (2003), Więzienie jako instytucja karna i resocjalizacyjna, Arche, Gdańsk.

Marczewski M. (2008), Teologia resocjalizacji [w:] Dylematy wspótczesnej profilaktyki i resocjalizacji, A. Kieszkowska (red.), UHP, ŚCPiE, Kielce, s. 77-85.

Masten A., Powell J.L. (2003), A Resilience Framework for Research, Policy and Practic [in:] Resilience and Vulnerability. Adaptation in the Context of Childhood Adversities, S. Luthar (red.), Cambridge University Press, Cambridge, s. 1-29.

Mudyń K. (2003), Czy można mieć zasoby, nie mając do nich dostępu? Problem dostępności zasobów [w:] Zasoby osobiste i społeczne sprzyjające zdrowiu jednostki, Z. Juczyński, N. Ogińska-Bulik (red.), Wydawnictwo UŁ, Łódź, s. 63-77.

Ostaszewski K. (2003), Skuteczność profilaktyki używania substancji psychoaktywnych. Podstawy opracowywania oraz ewaluacja programów dla dzieci i młodzieży, Wydawnictwo Scholar, Warszawa.

Ostaszewski K. (2010), Kompendium wiedzy o profilaktyce [w:] Przewodnik metodyczny po programach promocji zdrowia psychicznego i profilaktyki, Fundacja ETOH, Warszawa.

Pilch T. (1995), Grupa rówieśnicza jako środowisko wychowawcze [w:] Pedagogika społeczna. Człowiek w zmieniającym się świecie, T. Pilch, I. Lepalczyk (red.), Wydawnictwo Akademickie Żak, Warszawa, s. 174-186.

Przybysz-Zaremba M. (2008), Profilaktyka w szkotach gimnazjalnych województwa warminsko-mazurskiego [w:] Skuteczna resocjalizacja. Doświadczenia i propozycje, Z. Bartkowicz, A. Węgliński (red.), UMCS, Lublin, s. 315-320. 
Rejman J., Sak-Styczyńska A. (2008), Sprawność systemu profilaktyki i resocjalizacji warunkiem efektywności oddziaływań [w:] Skuteczna resocjalizacja. Doświadczenia i propozycje, Z. Bartkowicz, A. Węgliński (red.), UMCS, Lublin, s. 51-80.

Rękas A. (red.) (2010), Czy tylko sąd rozstrzygnie w sporze? Mediacja i sq̨downictwo polubowne, Warszawa, książka w pdf.

Rybczyńska D. (2008), Teoretyczne i praktyczne implikacje dla profilaktyki społeczno-wychowawczej [w:] Dylematy wspótczesnej profilaktyki i resocjalizacji, A. Kieszkowska (red.), UHP, ŚCPiE, Kielce, s. 67-76.

Sakowicz T. (2008), Zmierzch czy renesans zakładowej resocjalizacji [w:] Skuteczna resocjalizacja. Doświadczenia i propozycje, Z. Bartkowicz, A. Węgliński (red.), UMCS, Lublin, s. 29-42.

Szałański J. (2008), Zakres i poziom skuteczności resocjalizacji [w:] Skuteczna resocjalizacja. Doświadczenia i propozycje, Z. Bartkowicz, A. Węgliński (red.), UMCS, Lublin, s. 13-21.

Wdzięczna E.A. (2010), Warunkowe umorzenie postępowania karnego świetle koncepcji sprawiedliwości naprawczej, TNOiK, Toruń.

Wojnarska A. (2010), Pomiar kompetencji społecznych - przegląd zagadnień [w:] Diagnostyka resocjalizacyjna. Wybrane zagadnienia, A. Wojnarska (red.), UMCS, Lublin, s. 39-53.

Zubrzycka-Maciąg T. (2011), Rozwijanie asertywności u uczniów [w:] Kompetencje diagnostyczne i terapeutyczne nauczyciela, D. Wosik-Kawala, T. Zubrzycka-Maciąg (red.), Oficyna Wydawnicza „Impuls”, Kraków.

\section{Akty prawne}

Konwencja o prawach dziecka, 1989.

Ustawa o postępowaniu w sprawach nieletnich z dnia 26 października 1982 r. ze zm.

Rozporządzenie Ministra Sprawiedliwości z dnia 18 maja 2001 r. w sprawie postępowania mediacyjnego w sprawach nieletnich (Dz. U. z 2001 r. Nr 56, poz. 591).

Opinia Krajowej Rady Sądownictwa z dnia 10 lutego 2011 r. w przedmiocie projektu ustawy o zmianie ustawy o postępowaniu w sprawach nieletnich. 